NBER WORKING PAPER SERIES

\title{
THE COMPLEMENTARY ROLE OF EXPORTS AND R\&D INVESTMENTS AS SOURCES OF PRODUCTIVITY GROWTH
}

\author{
Bee Yan Aw \\ Mark J. Roberts \\ Tor Winston \\ Working Paper 11774 \\ http://www.nber.org/papers/w11774

\begin{abstract}
NATIONAL BUREAU OF ECONOMIC RESEARCH
1050 Massachusetts Avenue

Cambridge, MA 02138
\end{abstract} \\ November 2005
}

We are grateful to Mark Melitz, Steve Olley, Mark Schankerman, and Jim Tybout for helpful comments on earlier versions of this paper. The views expressed in this paper do not necessarily reflect those of the Department of Justice. The views expressed herein are those of the author(s) and do not necessarily reflect the views of the National Bureau of Economic Research.

(C2005 by Bee Yan Aw, Mark J. Roberts, and Tor Winston. All rights reserved. Short sections of text, not to exceed two paragraphs, may be quoted without explicit permission provided that full credit, including (C) notice, is given to the source. 
The Complementary Role of Exports and R\&D Investments as Sources of Productivity Growth Bee Yan Aw, Mark J. Roberts, and Tor Winston

NBER Working Paper No. 11774

November 2005

JEL No. F14, O12, D42

\section{ABSTRACT}

This paper examines two potential channels of knowledge acquisition that underlie firm productivity growth in the Taiwanese electronics industry: participation in the export market and investments in $\mathrm{R} \& \mathrm{D}$ and/or worker training. We focus on the argument that a firm's own investments in $\mathrm{R} \& \mathrm{D}$ are necessary for the firm to assimilate knowledge or expertise gained from foreign contacts and thus are an important component of the process of learning-by-exporting. Firm-level panel data from 1986, 1991, and 1996 is used to investigate a firm's decision to invest in these two activities and to assess the effects of these investments on the firm's future total factor productivity. The empirical model consists of four equations. The firm's decisions to export and invest in R\&D and/or worker training are modeled with a bivariate probit model that recognizes the interdependence of the decisions. We then estimate how participation in these investment activities alters the firm's future productivity trajectory while controlling for the potential selection bias introduced by endogenous firm exit. The primary empirical findings are that, on average, firms that export but do not invest in $\mathrm{R} \& \mathrm{D}$ and/or worker training have significantly higher future productivity than firms that do not participate in either activity. In addition, firms that export and invest in $R \& D$ and/or worker training have significantly higher future productivity than firms that only export. These findings are consistent with the hypothesis that export experience is an important source of productivity growth for Taiwanese firms and that firm investments in $R \& D$ and worker training facilitate their ability to benefit from their exposure to the export market.

Bee Yan Aw Department of Economics Pennsylvania State University University Park, PA 16802 byr@psu.edu
Mark J. Roberts Department of Economics Pennsylvania State University University Park, PA 16802 and NBER mroberts@psu.edu
Tor Winston Antitrust Division U.S. Department of Justice Washington, DC tor.winston@usdoj.gov 


\section{Introduction}

Recent empirical research based on micro-level data from several countries has overwhelmingly shown that large and persistent productivity differences among firms are significantly correlated with their export status. The majority of these studies have concluded that the higher productivity generally exhibited by exporting firms can be better explained by the self-selection of more efficient firms into the export market rather than by an increase in productivity that results from the expertise and knowledge gained through export experience, a process referred to as learning-by-exporting. ${ }^{1}$

While the micro evidence for learning-by-exporting is weak, the studies in this area have omitted a potentially important element of the process of productivity change: the investments made by firms to absorb and assimilate knowledge and expertise that they may gain from foreign contacts. Researchers examining the process of technological improvement in developing countries point to the critical role of investments, such as research and development and on-the-job-training, that are undertaken by firms attempting to assimilate newly-acquired technology from abroad. If participation in the export market acts as a conduit for foreign expertise, then the productivity effect of export market participation may depend on the firm's own in-house capability to assimilate new information.

In this paper we estimate a model of a firm's decisions to participate in the export sector and/or make investments in research and development (R\&D) and/or worker training (WT). We then examine how participation in these activities influences a firm's future productivity trajectory. Throughout the analyses we emphasize the potential interaction effects between participation in the export market and

\footnotetext{
${ }^{1}$ Clerides, Lach and Tybout (1998) use data from Colombia, Mexico and Morocco; Bernard and Jensen (1999) study U.S. manufacturing firms; Aw, Chung and Roberts (2000) use data from Taiwan and South Korea; Bernard and Wagner (1997) for Germany; Liu, Tsou, and Hammitt (1999) for Taiwan; Delgado, Farinas and Ruano (2002) use data from Spain; Baldwin and Gu (2003) study Canada and Greenaway and Kneller (2004) study the United Kingdom. All find evidence that more efficient producers self-select into the export market. Evidence of learningby-exporting is provided in Aw, Chung, and Roberts (2000) who observe productivity improvements following entry into the export market for a few Taiwanese industries. Baldwin and $\mathrm{Gu}$ (2003) find that there are subsequent productivity improvements (declines) for Canadian manufacturing plants that enter (exit) the export market. Greenaway and Kneller (2005)find that industry differences are an important marker for determining whether learning effects boost productivity after export market entry.
} 
investing in $\mathrm{R} \& \mathrm{D}$ and worker training. We estimate the model for the Taiwanese electronics industry using a panel data set constructed from firm surveys taken in 1986, 1991 and 1996.

Questions regarding the ability to assimilate foreign technology are especially relevant in this industry because it is regularly cited as possessing the ideal characteristics for "export-related technology transfer." A Taiwanese electronics manufacturer's ability to maintain global competitiveness hinges on its ability to continuously acquire and adapt new technologies. Researchers working on technology development in East Asian countries have argued that the recent spectacular growth of the industry would not have been possible without the combination of easy access to foreign technology and firms' efforts to assimilate this technology. ${ }^{3}$ High rates of export participation and large formal expenditures on both $\mathrm{R} \& \mathrm{D}$ and worker training, relative to other industries, make the electronics industry an appropriate focus of study of the interactions between exporting, R\&D investment, and productivity change.

Our results confirm a common empirical finding from the studies that use micro panel data to quantify the relationship between exporting and productivity. Export market participation exhibits significant persistence and is fundamentally related to firm-level variation in productivity. That is, firms with export experience, regardless of whether they also invest in R\&D or worker training (WT), and firms with higher productivity are both more likely to export. This finding is consistent with the hypothesis that initial entry into the export market involves some sunk costs and that high-productivity firms are more likely to self-select into the export market.

We also find econometric evidence to support anecdotal and case study evidence suggesting that exporting firms benefit from technology that is transferred from foreign customers. While there are no

\footnotetext{
${ }^{2}$ This expression, attributed to Westphal (2002), refers to the transfer of technology that takes place through the export activity, such as when purchasers of exports transmit some of the technology required to fulfil their orders, in a way that significantly affects the technological development of the industry.

${ }^{3}$ Hobday (1995b) and Westphal (2002) provide a case study of extraordinary export-related technology transfer in the electronics industry.
} 
complementarities between a firm's decision to export and invest in R\&D/WT, these two activities do have complementary effects on a firm's future productivity. There is a robust, positive, and statistically significant relationship between a firm's export market participation, with or without investments in R\&D/WT, and its future productivity. Exporters that also invest in R\&D/WT have significantly higher future productivity than firms that only export, a finding consistent with the view that expenditures on $\mathrm{R} \& \mathrm{D}$ and worker training facilitate a firm's ability to benefit from exposure to the export market.

Section II provides background regarding government policies toward export activities, R\&D, and worker training in Taiwan as well as a review of the relevant case study and econometric literature on learning-by-exporting and R\&D/WT investments. It also includes a brief description of our data and a summary of exporting, $\mathrm{R} \& \mathrm{D}$, and worker training activities among the firms in the Taiwanese electronics industry . The theoretical framework underlying our empirical model is described in Section III, followed by a description of the empirical model and the estimation results in Section IV. The final section is a summary of the results and conclusions.

\section{Patterns of Export Participation, R\&D and Worker Training Investments in Taiwan}

Background The bulk of Taiwan's exports are made-to-order and sold under foreign buyer's brand names (see Hobday (1995a)). Case studies suggest that these foreign buyers, eager to purchase from a cheaper source, often provide Taiwanese manufacturers with product designs and technical assistance to upgrade their technology to meet international quality standards and specifications (See Evenson and Westphal (1995) and World Bank (1993)). According to Gee and Kuo (1998), Taiwanese electronics firms benefitted greatly from these new opportunities and gradually learned to design new products for different customers. To the extent that these contacts with foreign buyers lead to incremental and significant technological change, participation in the export market can be a source of productivity gains for the firm. In this paper, we treat exporting as both an outcome of a firm's profit maximization 
decision as well as an investment intended to improve future productivity through learning-by-exporting.

However, building expertise or capability depends on more than just easy access to new technology. Research on the development of advanced technology in developing countries yields two principal messages relevant for our study. First, the most effective way of acquiring technological capability generally takes the form of continuous, incremental modifications, principally by firms, to adapt new technologies to fit specific situations or production conditions (Dosi (1988), Bell and Pavitt (1993)). Second, building technological capability depends fundamentally on firms' own investments in R\&D and developing human resources and skills, particularly through on-the-job training (Cohen and Levinthal (1989), Lucas (1993), Hewitt and Wield (1992) Dollar (1992), Mody (1993), and Audretsch (1995), Basant and Fikkert (1996)). According to these authors, R\&D not only generates new information, but also enhances the firm's ability to assimilate and exploit existing information. Therefore, the productivity effect of knowledge gained through export experience may depend on the firm's own investment in R\&D or worker training.

This facilitating role of $R \& D$ in improving firm efficiency has been recognized by many researchers. Griffith, Redding, and Van Reenan (2004) use a panel of industries across twelve OECD countries and find evidence that R\&D investments enhance technology transfer by improving firms' absorptive capacity. Consequently, industries in countries that lag behind the productivity frontier can catch-up particularly fast if they invest heavily in R\&D. Klette (1996) also finds evidence among Norwegian manufacturing plants which suggests those plants with $R \& D$ investments in the past have higher productivity growth. Griliches $(1979,1986)$ concludes that R\&D contributes significantly to productivity growth, and that privately-financed $R \& D$ expenditures have a significantly larger effect on private productivity and profitability than federally-financed $R \& D$. In Taiwan, private investments in $\mathrm{R} \& \mathrm{D}$ and worker training have grown more quickly than public expenditures on the activities since the mid-1980s. 
Aw and Batra (1998) is one of a few papers to analyze the interaction between exports and investments in R\&D and worker training. Using firm-level cross-section data from the 1986 Taiwan Census of Manufactures, they find that the individual effects of the export activity and R\&D/WT activity are positively and significantly correlated with an index of firm efficiency. Firms that simultaneously export and invest in R\&D and worker training are about 10-17 percent more efficient than those that only export. Because their data is cross sectional, the authors are unable to separate a firm's endogenous decision to export or invest in R\&D from the effects of these activities on firm productivity. Finally, Baldwin and $\mathrm{Gu}(2004)$ use data on Canadian manufacturing plants to analyze the link between entry into export markets and increases in investments in $\mathrm{R} \& \mathrm{D}$ and training. They find that exporters are also more likely to invest in advanced technology to enhance their absorptive capacity.

Taiwan Data To estimate the determinants of a firm's exporting and investments in R\&D/WT and their subsequent effects on productivity evolution we would like micro data with sufficient cross-sectional and intertemporal variation in firm investments. Every five years the Statistical Bureau of Taiwan's Executive Yuan conducts a census of the Taiwanese manufacturing sector. Among the data collected are information on each firm's sales, total employment, value of capital stock, and expenditures on wages, materials and subcontracting. These data allow for the construction of a total factor productivity (TFP) measure for each firm. ${ }^{4}$ The observations in the separate censuses are linked across the years (1986, 1991, and 1996) and we use them to track the evolution of each firms' productivity over time and entry and exit patterns. ${ }^{5}$ The census also distinguishes domestic sales from foreign sales so it is possible to identify exporters and non-exporters and measure firms' export intensities.

\footnotetext{
${ }^{4}$ We measure TFP with the multilateral Tornqvist index developed by Caves, Christensen, and Diewert (1982). Details of our TFP measure are provided in Aw, Chen, and Roberts (2001).

5 Because there are, at most, only three time series observations for a firm, we will not be able to identify detailed lag structures or diffusion patterns between knowledge investments and productivity. Because the data are at five-year intervals, we will focus on long-term changes in productivity.
} 
In each census year a sample of the larger and more technologically-advanced firms are asked to provide information regarding their expenditures on $R \& D$ and worker training. $R \& D$ expenditures include those incurred to improve existing production technology, marketing, expenditures to upgrade the quality of sales and service, and in the development of new products. Thus these expenditures reflect investments to reduce costs by improving the production process and to develop and introduce new and improved products. Worker training expenditures are defined as "expenditures in on-the-job training of firm personnel, including salary and any costs incurred in improving employees' operational capabilities. For this study we combine data on the firms' investments in R\&D and worker training collected in the survey with data on export participation, inputs and outputs from the census to analyze the effects of these investments on a firm's TFP.

In the empirical analysis we combine expenditures on $R \& D$ and worker training into one variable, R\&D/WT. We do so because only a small group of firms in each year chose to invest in one of the two activities but not the other, and thus it is difficult to identify the separate effects of the two activities in the empirical model. Instead, we focus on separating the effects of exporting from the effects of internal investments in either R\&D or worker training.

Tables 1 and 2 present counts of firm participation patterns in these activities. Table 1 classifies each firm according to whether it participated in neither activity, export only, R\&D/WT only, or both activities and reports the number of firms in the survey in each group in each year. In 1986, almost 52 percent of all firms in the survey had expenditures on either R\&D and/or WT and almost 72 percent participated in the export market. In each year a substantial share of the exporting firms chose to invest in R\&D/WT as well. Over the period covered by the panel, between 24 and 46 percent participated in both activities and between 22 and 41 percent of the firms in each year did not participate in either activity. Overall, the export activity was more prevalent among firms than participation in R\&D and/or worker training. While 25 to 30 percent of the firms in each year choose to export but not invest in 
$\mathrm{R} \& \mathrm{D} / \mathrm{WT}$, there are relatively few firms, approximately 5 percent per year, that invested only in R\&D/WT.

While Table 1 summarizes firm investment behavior in each cross section but it does not indicate how firm participation decisions persist or change over time. Table 2 summarizes information about changes in firms' investment choices and illustrates how the initial state of investment activities is related to the decision to start or stop each activity. The columns in Table 2 report the number and share of firms that initiate or cease each investment activity in period $t+1$, conditional on each firm's initial state in period $t$. For example, column 1 reports the number and proportion of firms in each of the four initial states that began investing in R\&D/WT.

Two general transition patterns emerge from Table 2. First, regardless of their initial state, a higher proportion of firms begin exporting than initiate investments in R\&D/WT and a lower proportion of firms cease exporting than cease investing in R\&D/WT. For example, of the 185 firms that did not participate in either activity in the initial period, 27 percent began exporting in the next period whereas only 13 percent began investing in R\&D/WT. Of the 530 firms that participated in both activities in year $t$, only 8 percent ceased to export while almost 30 percent stopped R\&D/WT investments in year $t+1$. Second, firms that participated in more activities in the initial year were less likely to cease their initial activity and more likely to have added an additional activity in year $t+1$. For example, in column 2, while only 29 percent of the firms that participated in both activities in the initial year ceased their investments in R\&D/WT, almost 44 percent of the firms that only invested in R\&D/WT in the initial year ceased that activity. Similarly, in the next column, only 27 percent of firms that did not participate in either activity in the initial year chose to start exporting. In contrast, 51 percent of firms that invested in $\mathrm{R} \& \mathrm{D} / \mathrm{WT}$ in the initial year chose to start exporting.

Taken together, we find evidence from simple counts of various activities in the panel data that history matters substantially in determining current investment choices. In particular, export 
participation demonstrates more persistence than R\&D/WT investment behavior and firms that participate in more activities initially are more likely to add new activities and less likely to cease their initial activity.

\section{A Theoretical Model of a Firm's Investment in Knowledge}

The links between investments in knowledge-producing activities and productivity have long been the subject of empirical research, beginning with the focus on the importance of R\&D and on-thejob-training in the productivity of firms in more advanced countries to the emphasis on export-related technology transfer in rapidly-growing countries in East Asia. If new technologies diffuse from developed to developing country markets through firm contacts in the export market then an exporting firm may have higher productivity because foreign innovations become available to them or the contacts prevent wasteful duplication of the resources needed to duplicate the foreign innovation.

In this section we outline a theoretical model of a firm's investments in two types of activities that produce or acquire knowledge. The first type of activity includes investments in R\&D or worker training that generate knowledge internally in the firm. The second type of activity includes investments in acquiring knowledge external to the firm and could include experience gained through the export market or membership in industry trade groups. The dividing line between these categories is not precise and we use them only as a useful shorthand for thinking about the range of activities the firm can undertake to increase its knowledge and expertise.

Our theoretical framework follows the model of physical investment and market participation developed by Olley and Pakes (1996) and we will only outline the key pieces needed for the estimating model here. We begin by treating R\&D and worker training expenditures $r_{t}$ in year $t$ as a flow of investment that creates a stock of knowledge $R_{t}$ through the accumulation equation $R_{t+1}=\delta_{r} R_{t}+r_{t}$ where $\delta_{r}$ is the retention rate for internally-generated knowledge. Similarly, $x_{t}$ is defined as the flow of 
investment devoted to acquiring knowledge from external sources and this produces a stock of externally-generated knowledge $X_{t}$ through the accumulation equation $X_{t+1}=\delta_{x} X_{t}+x_{t}$. These knowledge stocks enter directly into the firm's production function as productive inputs, along with a firm-specific productivity or efficiency level $\omega_{t}$. The productivity level $\omega$ captures a number of factors including managerial efficiency and output quality that can lead to differences in measured output, holding inputs fixed. The firm's short-run profit function is denoted as $\pi_{t}\left(Z_{t}, \omega_{t}, R_{t}, X_{t}\right)$ where $Z$ is a set of exogenous prices for output and variable inputs and the levels of any fixed inputs.

In addition to their direct effect on output, the investments in internal or external knowledge acquisition can also affect the productivity level of the firm in future years by, for example, giving the firm access to a broader range of production techniques or allowing them to increase product quality. To capture this possibility, we assume the firm's productivity level evolves over time as a Markov process where the firm's investments in knowledge activities, $r$ and $x$ shift the probability distribution of future productivity levels. Specifically, the evolution of firm productivity over time is represented by a distribution function

$$
F\left(\omega_{t+1} / \omega_{t}, r_{t}, x_{t}\right)
$$

Conditional on current productivity, firms that make investments in $r$ and $x$ should have a more favorable distribution for their productivity level in the future. ${ }^{6}$

In each year $t$, an incumbent firm makes two decisions. The first is a decision to continue in operation or to exit production. The decision to continue is made by comparing the maximum of the sum of the future discounted profits with the scrap value that could be earned by exiting. Second, given that the firm remains in operation, they choose the optimal levels of the investments $r_{t}$ and $x_{t}$. Olley and Pakes provide a characterization of the optimal investment and shut-down decision of the firm. The

\footnotetext{
6 The model of Olley and Pakes (1996) assumes that the distribution of future productivity is only dependent on current productivity so that the firm has no direct effect on the evolution of its future productivity. Ericson and Pakes (1995) develop a theoretical model of market evolution in which the distribution of future productivity is dependent on both current productivity and a single continuous investment variable which the firm chooses.
} 
solution to this optimization problem generates a shut-down rule for the firm that takes the form:

$$
\begin{aligned}
S_{t} & =1 \text { if } \omega_{t} \geq \underline{\omega}_{t}\left(R_{t}, X_{t}\right) \\
& =0 \text { otherwise. }
\end{aligned}
$$

$S_{t}$ is a discrete random variable that equals 1 if the firm remains in business in year $t$. It indicates that if firm productivity $\omega_{t}$ is above a threshold level $\underline{\omega}_{t}\left(R_{t}, X_{t}\right)$ then the firm will choose to remain in operation rather than take the scrap value and exit the industry. This discrete continuation decision will be one of the equations we estimate in the empirical section.

Second, the model produces demand equations for the two investment variables:

$$
r_{t}=r_{t}\left(\omega_{t}, R_{t}, X_{t}, Z_{t}\right) \quad \text { and } \quad x_{t}=x_{t}\left(\omega_{t}, R_{t}, X_{t}, Z_{t}\right)
$$

The period $t$ state variables, $\omega_{t}, R_{t}$, and $X_{t}$, are determinants of the firm's decision to shut down, invest in $R \& D$, and export, equations (2) and (3). In addition, exogenous demand and cost shifters, such as variable factor prices, output prices, and the levels of fixed factors are also determinants of profits and are necessary as controls.

\section{An Empirical Model of Firm Investment, Survival and Productivity}

The empirical model consists of the investment-expenditure equations (3), the probability of firm survival equation (2), and the assumption about the determinants of productivity evolution equation (1). The general goal of the empirical model is to quantify the relationships between productivity, export participation, and investments in $\mathrm{R} \& \mathrm{D}$ and/or worker training and to test if some of the intertemporal links do not exist. Given the hypothesized complementarities between R\&D/WT investments and export participation, we are especially interested in empirical evidence about interaction effects between these variables.

\section{Export Participation and $R \& D / W T$ Investment Expenditures}

The theoretical model specifies the firm's investments in internal and external sources of 
knowledge as functions of the accumulated stocks of these variables, as well as productivity and some additional profit shifters, equation (3). Given the relatively short time period covered by our data and the fact that observations are five years apart, we cannot construct measure of knowledge stocks. Instead, we proxy these stocks with dummy variables that indicate which combination of the export and $\mathrm{R} \& \mathrm{D} / \mathrm{WT}$ activities each firm chose in the previous year, $t-1 .{ }^{7}$ In addition we choose to model the current investment decisions as a discrete choice. We specify the R\&D/WT investment and exporting equations as two separate binary decisions using a bivariate probit model. The export and R\&D/WT choices for firm $i$ in year $t$ are written as:

$$
\begin{aligned}
& I\left(\text { Export }_{i t}\right)=a_{0}+a_{t}+a_{1} \log \left(a_{i t}\right)+a_{2} I\left(E_{i t}\right)+a_{3} \log \left(k_{i t}\right) \\
& +a_{4} \log \left(\text { pwage }_{i t}\right)+a_{5} I\left(\text { multiplant }_{i t}\right)+a_{6} \omega_{i t}+a_{7}\left(\omega_{i t}\right)^{2}+ \\
& \sum_{k=1}^{3} b_{k} I\left(\text { Choice }_{i t-1}^{k}\right)+\sum_{k=1}^{3} b_{k k} \omega_{i t} I\left(\text { Choice }_{i t-1}^{k}\right)+\mathcal{E x}_{i t} \\
& I\left(R \& D / W T_{i t}\right)=c+c_{t}+c_{1} \log \left(a_{i t}\right)+c_{2} I\left(E_{i t}\right)+c_{3} \log \left(k_{i t}\right) \\
& +c_{4} \log \left(\text { pwage }_{i t}\right)+c_{5} I\left(\text { multiplant }_{i t}\right)+c_{6} \omega_{i t}+c_{7}\left(\omega_{i t}\right)^{2}+ \\
& \sum_{k=1}^{3} d_{k} I\left(\text { Choice }_{i t-1}^{k}\right)+\sum_{k=1}^{3} d_{k k} \omega_{i t} I\left(\text { Choice }^{k}{ }_{i t-1}\right)+\varepsilon r_{i t}
\end{aligned}
$$

where $I\left(\right.$ Export $\left._{i t}\right)$ is an indicator variable equal to one for firms that export and $I\left(R \& D / W T_{i t}\right)$ is an indicator variable equal to one for those that invest in $R \& D$ or worker training. This specification excludes any source of intertemporal correlation in the errors but it does allow the contemporaneous correlation in the errors terms of the two choices, $\operatorname{Corr}\left(\epsilon x_{i t}, \epsilon r_{i t}\right)$, to be nonzero. ${ }^{8}$

\footnotetext{
${ }^{7}$ This dynamic discrete choice specification is identical to a model in which the decision to invest is subject to a sunk cost that must be paid prior to investment. Roberts and Tybout (1997) develop a discrete model of firm exporting that leads to the discrete decision to export being a function of the lagged export variable. The regression coefficient on the lagged export variable is a measure of the size of the sunk cost of entry. In this case a nonzero coefficient on lagged R\&D or lagged worker training is consistent with sunk costs of adjustment on each variable.

${ }^{8}$ We also used a multinomial probit model to specify the probability of choosing each of four possible combinations of the two discrete investment choices of R\&D and export activities. In this specification we included a random firm effect that is correlated across choices and allowed for transitory sources of serial correlation in each decision. The results of that estimation indicate that neither the random firm effect or transitory serial correlation are important in
} 
The explanatory variables, in order, are a constant term, year dummy, the log of the firm's age, a dummy variable equal to one if the firm was an entrant between year $t-2$ and year $t-1$, the $\log$ of the firm's capital stock, the log of the firm's average production worker's wage, a dummy variable equal to one if the firm has multiple plants. These right-hand-side variables capture the profit shifters specified by $Z$ in the theoretical model. The remaining explanatory variables are productivity, productivity squared, and three dummy variables, $I\left(\right.$ Choice $\left.^{k}{ }_{i t-1}\right), k \in\{1,2,3\}$, that capture past investments in R\&D/WT and/or participation in the export market in year $t$ - 1 . These lagged choice variables are the proxies for the internal and external knowledge stocks. Firms that invested in R\&D or exported in the prior census have some experience with these activities and this specification will allow us to measure if that experience is correlated with current investments. The lagged choice variables distinguish three cases: firms that both exported and invested in R\&D/WT (choice 1), firms that exported only (choice 2), and firms that invested in R\&D/WT only (choice 3). The omitted or base case is a firm that did neither activity. Finally, there are three interaction terms that capture potential relationships between the past discrete choices and current productivity.

\section{Firm Survival and Productivity Evolution}

The theoretical model developed in Section III assumes that a firm's productivity evolves according to the Markov process specified in equation (1). The productivity process is conditional on a firm's investments in R\&D/WT and export market participation. The empirical specification of equation (1) estimates the marginal contribution of current investments in R\&D/WT and export market participation to the mean level of a firm's productivity in year $t+1$ while controlling for the firm's current level of productivity. The productivity equation is specified as:

$$
\omega_{i t+1}=\gamma_{0}+\sum_{k=1}^{3} \gamma_{k} I\left(\text { Choice }_{i t}{ }^{k}\right)+\gamma_{4} \omega_{i t}+v_{i t+1}
$$

\footnotetext{
the data. The simpler bivariate probit model captures all the important patterns in the data and error terms and we just focus on those results in this paper. See Winston (2001) for discussion of the multinomial probit model and results.
} 
Since we only observe $\omega_{i t+1}$ for the firms that survive to period $t+1$, the estimated coefficients of the model may suffer from a selection bias if random factors that affect a firm's survival to period $t+1$ also affect its productivity in that year. For example, an unobserved firm-specific demand shock that boosts current productivity may induce the firm to remain in the market and thus introduce correlation between survival and future productivity. To correct for this bias we employ Heckman's sample selection framework and jointly estimate the productivity evolution equation (6) with an equation for firm survival. The survival decision is specified in (2) and modeled empirically as:

$$
\begin{aligned}
S_{i t+1}= & \eta_{0}+\eta_{t}+\eta_{1} \log \left(a_{i t}\right)+\eta_{2} I\left(E_{i t}\right)+\eta_{3} \log \left(k_{i t}\right) \\
& +\eta_{4} \log \left(\text { pwage }_{i t}\right)+\eta_{5} I\left(\text { multiplant }_{i t}\right)+\eta_{6} \omega_{i t}+\eta_{7}\left(\omega_{i t}\right)^{2}+ \\
& \left.\left.\sum_{k=1}^{3} \eta^{k} \text { I }_{\text {Choice }}{ }_{i t}\right)+\sum_{k=1}^{3} \eta^{k k} \omega_{i t} I_{\left(\text {Choice }_{i t}{ }^{k}\right.}\right)+\xi_{i j t+1}
\end{aligned}
$$

Equations (6) and (7) are estimated jointly using maximum likelihood. The model includes one additional parameter, the $\operatorname{Corr}\left(\xi_{i t+1}, v_{i t+1}\right)$, which measures the correlation between the errors in the survival and productivity equations. Both equations also include a set of three-digit industry dummies to control for industry-level differences in the failure and productivity growth rates. The selection equation includes a set of plant-level variables $\left(I\left(E_{i t}\right), \log \left(a_{i t}\right), \log \left(k_{i t}\right), \log \left(k_{i t}\right)^{2}, \log \left(\right.\right.$ pwage $\left._{i t}\right), I\left(\right.$ multiplant $\left.\left._{i t}\right)\right)$ that are omitted from the productivity equation and aid in identification.

\section{Empirical Results}

Investment Equations The results of the bivariate probit model of investment are reported in Table 3. Moving down the table, the coefficients indicate that: recent entrants are significantly more likely to participate in either activity, firms with more capital are more likely to engage in either activity, and higher productivity increases the probability of exporting by the firm but does not significantly affect the probability of investing in R\&D/WT. The diminishing effect of productivity in the export decision is also significant. Production wages are negatively correlated with the probability of exporting, a pattern 
that is not present in developed country studies. ${ }^{9}$ The coefficients on the lagged choice variables indicate that firms with export experience, either on its own (choice 2) or in conjunction with R\&D/WT experience (choice 1), are more likely to export in the current period. While firms that have experience in both activities are more likely to invest in R\&D/WT in the current period, experience in R\&D/WT on its own (choice 3) has no significant effect on either current decision. The interactions between $\omega_{i t}$ and a firm's past choices are insignificant in both equations. The estimated value of $\operatorname{Corr}\left(\epsilon x_{i t}, \epsilon r_{i t}\right)$ is a positive 0.287 and statistically significant. Shocks that lead a firm to participate in one activity tend to lead it to participate in both.

Overall, the empirical patterns for the export decision duplicate findings from most other studies. In particular, current export participation is positively correlated with productivity, capital stock (or firm size) and past export participation. The latter can reflect either other sources of profit heterogeneity among producers, with profitable producers remaining in the export market, or the effect of sunk entry costs on the participation decision (see Roberts and Tybout (1997)). One pattern that is new to this study is the importance of the interaction effect between past exporting and R\&D investment. Firms in this category are most likely to continue exporting, which is consistent with the argument that the return to exporting are greater for firms that have their own in-house capabilities to assimilate knowledge gained through the export market.

The empirical patterns for the R\&D investment decision show that larger firms (as measured by capital stock) and, in this industry, younger firms are the primary groups that invest in R\&D. The latter finding is not typical in R\&D studies, which generally find that $R \& D$ is concentrated in older, larger firms, and may reflect the unusual dynamic nature of this industry and time period. There is less evidence of persistence over time in $R \& D$ investment than in exporting status, which mirrors the turnover patterns reported in Table 2. This could reflect that startup and shutdown costs are smaller for R\&D

\footnotetext{
${ }^{9}$ This is likely a result of the structure of our sample, which is dominated by the larger, more technically sophisticated producers and does not include the very smallest firms, which tend to pay lower wages and not export.
} 
operations than for exporting or that the $\mathrm{R} \& \mathrm{D}$ spending does not reflect long-term commitments to innovation activities by many of the firms.

While the discrete choice models inform us about a firm's decisions to participate in the export market or invest in R\&D/WT, they say nothing about the intensity with which firms engage in these activities. In contrast to the discrete choice models, it is difficult to construct useful measures of interactions between a firm's chosen export and R\&D/WT intensities. Therefore, in assessing the effect of the state variables on a firm's R\&D/WT and export intensities, we focus on a separate equation for each choice. We measure a firm's R\&D/WT intensity as the share of total revenue that is invested in $\mathrm{R} \& \mathrm{D}$ and/or worker training. A firm's export intensity is similarly defined as the share of total revenue that it derives from exports. We replace the three lagged choice dummies with two lagged intensity measures and estimate each equation using only the firms that participate in the respective activities. ${ }^{10}$ In this specification we also include a random firm effect because we find substantial serial correlation in the error terms. The estimated results of the two intensity equations are reported in Table 4.

Two differences in the Table 4 results stand out when compared to the probit specifications. First, while capital is an important determinant of a firm's discrete decisions to participate in the R\&D/WT and export activities, it plays no significant role in determining the intensities of those that do participate. Second, while firms with high $\omega_{i t}$ are more likely to participate in the export market, productivity is either not significant (in the export intensity equation) or significantly negative (in the $\mathrm{R} \& \mathrm{D}$ intensity equation). ${ }^{11}$ The latter finding is consistent with the fact that high productivity firms may have less incentive to invest intensively because the return to further investments is low. Some minimal investment in R\&D/WT may be necessary to maintain a firm's absorptive capacity, but that the return on

\footnotetext{
${ }^{10}$ An alternative would be to specify two tobit equations that would each estimate both the discrete and continuous participation and investment decisions. The results from this specification are very similar to the bivariate probit results reported in table 3 .

${ }^{11}$ Aw, Chung, and Roberts (2000) find a significant positive relationship between firm productivity and participation in the export market for Taiwanese electronics firms, but no relationship between productivity and export intensity.
} 
investments intensity diminishes with the firm's productivity.

Finally, the results on the lagged intensity measures differ from those in the probit specifications. While past participation in R\&D/WT investments had no significant effect on any current investment decisions in the discrete choice model, firms that made more intensive investments in R\&D/WT in the pervious period tend to invest less intensively in those activities today. This could reflect diminishing returns to these activities or an investment process in which periods of high investment are followed by periods of low investment. Given the five-year gap between our time observations, however, it is not possible to sort out these explanations. Similarly, firms that were intensive exporters in the past tend to export less intensely today although this coefficient is not statistically significant. There is little evidence of complementarities in that past intensity in one activity has no significant effect on a firm's current intensity of the other activity. Overall, the investment shares appear much less systematic and more likely to be driven by firm-specific unobservable factors than the discrete decision to engage in the activity. Year-to-year fluctuations in investment intensity are more likely to reflect noise than are the fluctuations in participation patterns and we prefer the discrete investment equations for this reason.

\section{Productivity Evolution and Firm Survival}

The second part of the empirical model focuses on the effect of these investments on the firm's survival and future productivity growth. The estimated parameters reported in Table 5 indicate the determinants of a firm's survival. When all other factors are accounted for, current productivity does improve a firm's chances of survival, but the 0.290 estimated effect is only significant at the $10 \%$ level. Both entrant status and capital stock are important determinants of a firm's survival. Recent entrants are more likely to fail, a finding that is consistent with many firm-level empirical studies in both developed and developing countries. Firms with larger capital stocks have a higher probability of remaining in operation and this likely to reflect the fact that firms with large capital stocks are more likely to be able to cover their variable costs. The negative and significant coefficient on $\log \left(k_{i}\right)^{2}$ indicates that this effect is diminishing in firm size. Beyond its entry status, a firm's age and multi-plant status do not have a 
significant effect on its survival. The positive and significant coefficients on the industry dummies indicate that there is substantial variation in survival rates across more disaggregated electrical product industries which can reflect demand conditions that are unique to each product market.

The results on the prior investment variables indicate that firm survival is generally not significantly related to prior exporting or R\&D/WT investments. These findings are not consistent with the theoretical model, which predicts that participation in these activities affects a firm's survival decision. It also contrasts with the findings of Bernard and Jensen (1999) who find that, while export experience played little role in a firm's productivity growth in US data, it did improve a firm's probability of survival. However, the insignificance of participation in R\&D/WT and export found in our data may be due to the length of time between our observations. Over the span of five years there are many opportunities for changes in the markets to result in firm exit.

Table 6 reports the coefficient estimates for the productivity evolution equation. The positive and significant coefficient on current productivity (0.279) is expected, reflecting the fact there is persistence in the productivity ranking of firms over time. The coefficients on the firm's prior export participation and $\mathrm{R} \& \mathrm{D} / \mathrm{WT}$ investment decisions support the hypothesis that $\mathrm{R} \& \mathrm{D} / \mathrm{WT}$ and export experience have complementary effects on a firm's productivity. The argument put forth in the case study literature is that firms that invest in $R \& D$ and worker training are better equipped to absorb the ideas and technologies supplied by the foreign buyers. Therefore firms that invest in R\&D/WT in addition to exporting should experience an additional return on their exposure to the export market. The coefficient estimates in the first column of Table 6 indicate that the complementarities exist. The positive and significant coefficient on choice 2 indicates that firms that only export in the current period have 4.2 percent higher productivity, on average, five years later. The coefficient on choice 1 is also significantly different from zero, and indicates that firms that participate in both activities have, on average, 7.8 percent higher productivity in the next period. In addition, a Wald test reveals that the coefficient on Choice 1 is significantly different from the coefficient on Choice 2 at the $5 \%$ level. This 
indicates that firms that combine R\&D/WT and export participation experience a larger productivity increase than the firms that only export. The coefficient on choice 3 (only investing in R\&D/WT) is positive but statistically insignificant. These results are consistent with the claim that firms that invest in $\mathrm{R} \& \mathrm{D}$ or worker training are better able to absorb the knowledge gained from exporting.

As suggested by the results of the bivariate probit specifications, high productivity firms may gain more than low productivity firms from participating in each investment activity. Therefore, one would expect that a firm's return to each activity (in terms of higher future productivity) to depend on its current productivity. This hypothesis can be tested by including interactions between $\omega_{i t}$ and each of the three choice dummies in the model. The results of this alternative specification are reported in the second column of results in Table 6 . The intercept, year dummy, and productivity coefficients in the second of results column are similar to those in the first column. While the coefficient on Choice 1 remains relatively unchanged, the coefficients on Choice 2 and Choice 3 increase and are both statistically significant. Although not statistically significant, the negative coefficients on the interaction terms between $\omega_{t}$ and the three choices are consistent with the prediction that higher productivity firms benefit less from participating in these activities than do lower productivity firms. The combined effect of the choice dummies and their interactions indicate that, for the average firm with $\omega_{t}=0.258$, there is still a significant difference between the effect of exporting only (choice 2) and exporting in conjunction with R\&D/WT (choice 1) at the 5\% significance level. For firms with higher productivity this difference becomes even more significant. This indicates that the contributions of R\&D and worker training to a firm's absorptive capacity depend on its current productivity.

The final result of the empirical model indicates that unexplained shocks that increase a firm's chance of survival are negatively correlated with its future productivity if it does survive $\left(\operatorname{Corr}\left(\xi_{i t}, v_{i t}\right)=\right.$ -0.152). However, the standard error on the estimated correlation is 0.218 and a likelihood ratio test can not reject the hypothesis of independence between the survival and the productivity evolution equations. Therefore, it appears that the issue of endogenous exit of firms has little effect on the parameters of the 
evolution equation. ${ }^{12}$ One additional empirical issue that arises in such a model is the possibility of serial correlation in the error terms. Differences in productivity may induce firms to make other investments or decisions with lasting effects on the evolution of their productivity. The effect of these unaccounted for actions could result in serially correlated errors and a biased coefficient on $\omega_{t}$. We perform a modified Breusch-Godfrey test for serial correlation but do not find any evidence of serial correlation.

Our key results from the estimation of the productivity evolution equation are twofold: first, firms with higher investments in exports, with or without R\&D/WT, have higher future productivity; second, the returns, in the form of higher future productivity, are almost twice as large for firms that export and invest in R\&D/WT relative to those that only export. The first result is consistent with learning-by-exporting among large Taiwanese electronic firms and the second result is consistent with the view that export related technology absorption is facilitated by investments in R\&D/WT.

\section{Summary and Conclusions}

This paper examines two specific channels of knowledge acquisition that underlie firm productivity growth: participation in the export market and investments in R\&D and/or worker training. We develop a theoretical and empirical model linking a firm's participation in the export market, investments in $\mathrm{R} \& \mathrm{D}$, and productivity using firm-level data for the Taiwanese electronics producers.

In the theoretical model, a firm's productivity evolves over time in a way that depends on initial productivity, current investments in $\mathrm{R} \& \mathrm{D}$ and worker training, and experience gained in the export market. Each firm makes decisions to remain in operation, invest in $R \& D$, and participate in the export market. All of these decisions are affected by the firm's initial productivity level. The empirical model consists of equations for the firm's R\&D investment, export market participation, survival, and

\footnotetext{
12 Because the sample selection is not critical to the estimation, we also estimate the productivity evolution equation using a random effects model that does not account for the selection bias. The results of this alternative specification are very similar to the results presented in Table 6 . The only difference is that the coefficient on Choice 3 (R\&D/WT only) is significant while it is not significant in the first column of Table 6.
} 
productivity evolution. The $\mathrm{R} \& \mathrm{D}$ and export decisions are treated as discrete and modeled with the bivariate probit model. The productivity evolution equation is estimated while controlling for the selection bias that arises from endogenous firm exit.

The findings indicate that the decision to export is affected by firm productivity. Higher productivity producers are more likely to be in the export market and this mirrors the findings of most other empirical studies of this relationship. Firms with prior export market experience are also more likely to participate and this is consistent with previous empirical findings that focus on sunk entry costs as a determinant of persistence in exporting patterns. Prior exporting and R\&D investments also increase the probability the firm invests in both activities, but prior R\&D expenditures alone do not have a significant effect on the firm's current investments. Overall, there appears to be more persistence in the firm's exporting than in their R\&D spending.

We also find a positive, statistically significant, and robust relationship between a firm's export market participation and its future productivity. The effect is larger if the firm has also made investments in R\&D. Researchers who have conducted case studies of Taiwanese industries have argued that firms that export benefit from technology that is transferred from their foreign customers and that this transfer is enhanced if the firm makes its own simultaneous investments to improve its ability to assimilate the new technology. Our empirical finding of higher future productivity for these firms is consistent with this argument.

Overall, the empirical findings are consistent with a development process in which firms are heterogenous in their underlying productivity but can affect their future productivity path by making investments that increase their knowledge base. In turn, higher productivity increases the return to these investments which results in additional investments that further expand the knowledge base. In the case of Taiwan, it has been argued that the two tools that have augmented the firm's knowledge base are export market contacts with developed country buyers and investments in R\&D which give them the capability to assimilate and utilize the new technology or ideas they gain from their foreign contacts. Our 
empirical findings are consistent with this process. In particular, for the electronics industry we find that export market participation is more than just the self-selection of more efficient firms into the export market. We find evidence consistent with the learning-by-exporting hypothesis whereby firms that export have significantly higher productivity growth than those that do not export. The robustness of the relationship between exports and future productivity suggests that the export activity is an important mechanism for technology transfer in this industry. 


\section{References}

Audretsch, David B. (1995), Innovation and Industry Evolution, Cambridge, Mass.: MIT Press.

Aw, Bee Yan, and Geeta Batra (1998), "Technological Capability and Firm Efficiency in Taiwan." World Bank Economic Review, Vol. 12. No. 1, pp.59-79.

Aw, Bee Yan, Xiaomin Chen, and Mark J. Roberts (2001), "Firm-Level Evidence on Productivity Differentials, Turnover and Exports in Taiwanese Manufacturing," Journal of Development Economics, Vol. 66, pp. 51-86.

Aw, Bee Yan, Sukkyun Chung and Mark J. Roberts (2000), "Productivity and Turnover in the Export Market: Micro-Level evidence from Taiwan (China ) and the Republic of Korea.", World Bank Economic Review, Vol. 14. No. 1, pp. 65-90.

Baldwin, J.R., and Gu, W. (2003), "Participation on Export Markets and Productivity Performance in Canadian Manufacturing," Canadian Journal of Economics, Vol. 36, No. 3, pp. 634-657.

Baldwin, J.R., and Gu, W. (2004), "Trade Liberalization: Export-Market Participation, Productivity Growth and Innovation," Oxford Review of Economic Policy, Vol. 20, pp. 372-392.

Basant, R. And B. Fikkert(1996), "The Effects of R\&D, Foreign Technology Purchase, and Domestic and International Spillovers on Productivity in Indian Firms," Review of Economics and Statistics, Vol. 78, No. 2, pp. 187-199.

Bell, Martin and Keith Pavitt (1993), "Accumulating Technological Capability in Developing Countries." In Proceedings of the World Bank Annual Conference on Development Economics 1992. Washington, D.C: World Bank.

Bernard, Andrew B. and J. Bradford Jensen (1999), "Exceptional Exporter Performance: Cause, Effect, or Both?” Journal of International Economics, Vol 47, No. 1, pp.1-25.

Bernard, Andrew B, and Joachim Wagner (1997), "Exports and Success in German Manufacturing," Weltwirtschaftliches Archiv, Vol. 133, pp. 134-157.

Caves, Douglas W., Laurits Christensen, and Erwin Diewert (1982), "Output, Input, and Productivity Using Superlative Index Numbers,” Economic Journal, Vol. 92, pp. 73-96.

Clerides, Sofronis, Saul Lach, and James Tybout (1998), "Is 'Learning-by-Exporting' Important? MicroDynamic Evidence from Colombia, Mexico, and Morocco," Quarterly Journal of Economics, Vol. 113 (August), pp. 903-47.

Cohen, Wesley M. and Daniel A. Levinthal (1989), "Innovation and Learning: The Two faces of R\&D," Economic Journal, Vol. 99, pp. 569-596.

Cohen, Wesley M. and Daniel A. Levinthal (1990), "Absorptive Capacity: A New Perspective on Learning and Innovation," Administrative Science Quarterly, Vol. 35, pp. 128-52. 
Delgado, Miguel A., Jose C. Fariñas, and Sonia Ruano (2002), "Firm Productivity and Export Markets: A Nonparametric Approach," Journal of International Economics, Vol. 57, No. 2, pp. 397-422.

Dollar, David (1992), "Exploring the Advantages of Backwardness: The Importance of Education and Outward Orientation," East Asia and Pacific Department, World Bank, Washington, D.C. Processed.

Dosi, G. (1988), "Sources, Procedures and Microeconomic Effects of Innovation," Journal of Economic Literature, Vol. 36, pp. 1120-71.

Ericson, Richard and Ariel Pakes (1995), "Markov-Perfect Industry Dynamics: A Framework for Empirical Work," Review of Economic Studies, Vol. 62, pp. 53-82.

Evenson, R.E. and L.E. Westphal (1995), “Technological Change and Technology Strategy,” in J. Behrman and T.N. Srinivasan (eds.), Handbook of Development Economics, 3A, Amsterdam: North Holland.

Gee, San and Wen-jeng Kuo (1998), "Export Success and Technological Capability: Textiles and Electronics in Taiwan Province of China." in Dieter Ernst, Tom Ganiatsos and Lynn Mytelka (eds.), Technological Capabilities and Export Success in Asia, London: Routledge.

Greenaway,David and Richard Kneller (2004), "Exporting and Productivity in the United Kingdom," Oxford Review of Economic Policy, Vol.20, pp. 358-371.

Greenaway,David and Richard Kneller (2005), "Industry Differences in the Effect of Export Market Entry: Learning by Exporting?," GEP Research Paper, Leverhulme Centre for Research on Globalization and Economic Policy, University of Nottingham.

Griffith, Rachel, Stephen Redding and John Van Reenan,(2004), "Mapping the Two Faces of R\&D: Productivity Growth in a Panel of OECD Industries," Review of Economics and Statistics, Vol 86, No. 4, pp. 883-895.

Griliches, Zvi (1979), "Issues in Assessing the Contribution of R\&D to Productivity," Bell Journal of Economics, Vol.10, pp. 92-116.

Griliches, Zvi (1986), "Productivity, R\&D, and Basic Research at the Firm Level in the 1970s," American Economic Review, Vol 76, No. 1, pp. 141-54.

Hewitt T. and D. Wield (1992), "Technology and Industrialization." in T. Hewitt, H. Johnson and D. Wield, (eds.), Industrialization and Development, Oxford: Oxford University Press.

Hobday, Michael (1995a), Innovation in East Asia: The Challenge to Japan, Brookfield, VT: Edward Elgar.

Hobday, Michael (1995b), "East Asian Latecomer Firms: Learning the Technology of Electronics," World Development, Vol 23, No. 7, pp. 1171-1193.

Klette, Tor Jakob (1996), “ R\&D, Scope Economies, and Plant Performance," RAND Journal of Economics, Vol 27, No. 3, pp. 502-522. 
Liu, Jin-Tan, Meng-Wen Tsou and James K Hammitt (1999), “Export Activity and Productivity: Evidence from the Taiwan Electronics Industry," Weltwirtschaftliches Archiv, Vol.35, pp. 675691.

Lucas, R. (1993), "Making of A Miracle," Econometrica, Vol. 61, pp. 251-272.

Mody, A. (1993), "Alternative Strategies for Developing Information Industries," in B. Wellenius, A. Miller and C. Dahlman (eds.), Developing the Electronics Industry, Washington D.C.: The World Bank.

Olley, G. Steven and Ariel Pakes (1996), "The Dynamics of Productivity in the Telecommunications Equipment Industry," Econometrica, Vol.64, No. 6, pp.1263-1297.

Roberts, Mark J. and James R. Tybout (1997), "The Decision to Export in Colombia: An Empirical Model of Entry with Sunk Costs," American Economic Review, Vol. 87, pp. 545-564.

Westphal, Larry E. (2002), "Technology Strategies For Economic Development in a Fast Changing Global Economy," Economics of Innovation and New Technology, Vol. 11, pp. 275-320.

Winston, Tor (2001), "Productivity Growth in the Taiwanese Electronics Industry: Inquiries Into the Effects of Exporting, Research and Development, Worker Training, and Local Knowledge Spillovers," unpublished Ph.D. dissertation, The Pennsylvania State University.

World Bank (1993), The East Asian Miracle: Economic Growth and Public Policy, Oxford: Oxford University Press. 
Table 1: Summary of Investment Activities Among Taiwanese Electronics Firms

Number of firms in each combination of activities (Percent of row total)

\begin{tabular}{|c|c|c|c|c|}
\hline \multirow{2}{*}{ Year } & \multicolumn{4}{|c|}{ Investment Activity } \\
& $\begin{array}{c}\text { No R\&D/WT } \\
\text { No Exporting }\end{array}$ & Only R\&D/WT & Only Exporting & $\begin{array}{c}\text { Both R\&D/WT } \\
\text { and Exporting }\end{array}$ \\
\hline \multirow{3}{*}{1986} & $\begin{array}{c}215 \\
(22.42)\end{array}$ & $\begin{array}{c}55 \\
(5.74)\end{array}$ & $\begin{array}{c}248 \\
(25.86)\end{array}$ & 441 \\
\hline 1991 & 713 & 90 & 508 & $45.99)$ \\
\hline & $(41.26)$ & $(5.21)$ & $(29.4)$ & $(24.13)$ \\
1996 & 476 & 90 & 355 & 500 \\
& $(33.5)$ & $(6.33)$ & $(24.98)$ & $(35.19)$ \\
\hline
\end{tabular}

Table 2: Transition Matrix of Investment Activities Between Years $t$ and $t+1,1986-1996$ Number of Firms (Row Proportion)

\begin{tabular}{|l|c|c|c|c|}
\hline \multirow{2}{*}{$\begin{array}{l}\text { Investment Activity year } t \\
\text { (number of firms in year } t \text { ) }\end{array}$} & \multicolumn{4}{|c|}{ year $(t+1)$} \\
\cline { 2 - 5 } & StartR\&D/WT & Stop R\&D/WT & Start Exporting & Stop Exporting \\
\hline $\begin{array}{l}\text { No R\&D/WT and No } \\
\text { Exporting (185) }\end{array}$ & $\begin{array}{c}24 \\
(12.97)\end{array}$ & - & $\begin{array}{c}50 \\
(27.03)\end{array}$ & - \\
\hline Only R\&D/WT (82) & - & $\begin{array}{c}36 \\
(43.90)\end{array}$ & $\begin{array}{c}42 \\
(51.22)\end{array}$ & - \\
\hline Only Exporting (276) & 73 & - & - & 52 \\
& $(26.45)$ & 156 & - & $(18.84)$ \\
\hline $\begin{array}{l}\text { R\&D/WT and Exporting } \\
\text { (530) }\end{array}$ & - & $(29.43)$ & - & 40 \\
\hline
\end{tabular}


Table 3: Discrete Investment Activity Equation

Bivariate Probit Estimates

\begin{tabular}{|l|c|c|}
\hline Variables & Exporting & R\&D/WT \\
\hline intercept & $-3.377(0.647)^{*}$ & $-6.749(0.626)^{*}$ \\
\hline year dummy & $0.137(0.108)$ & $0.023(0.096)$ \\
\hline entrant dummy & $0.647(0.162)^{*}$ & $0.593(0.199)^{*}$ \\
\hline $\log ($ age $)$ & $0.128(0.070)$ & $-0.209(0.069)^{*}$ \\
\hline $\log \left(k_{i t}\right)$ & $0.383(0.038)^{*}$ & $0.496(0.036)^{*}$ \\
\hline $\log \left(\right.$ pwage $\left._{i t}\right)$ & $-0.319(0.104)^{*}$ & $0.114(0.100)$ \\
\hline multiplant dummy & $0.067(0.127)$ & $0.035(0.111)$ \\
\hline productivity $\left(\omega_{i t}\right)$ & $1.12(0.356)^{*}$ & $0.524(0.283)$ \\
\hline$\left(\omega_{i t}\right)^{2}$ & $-0.631(0.272)^{*}$ & $-0.138(0.215)$ \\
\hline lagged Choice 1 dummy & $1.27(0.297)^{*}$ & $0.711(0.251)^{*}$ \\
Exporting and R\&D/WT & & $0.206(0.263)$ \\
\hline lagged Choice 2 dummy & $0.921(0.239)^{*}$ & $0.329(0.425)$ \\
Exporting but not R\&D/WT & & $0.193(0.416)$ \\
\hline lagged Choice 3 dummy & $-0.130(0.423)$ & $-0.045(0.415)$ \\
R\&D/WT but not Exporting & & $0.246(0.929)$ \\
\hline$\left(\omega_{i t}\right)^{*}$ lagged Choice 1 dummy & $-0.036(0.652)$ & \\
\hline$\left(\omega_{i t}\right)^{*}$ lagged Choice 2 dummy & $0.829(0.464)$ & \\
\hline$\left(\omega_{i t}\right)^{*}$ lagged Choice 3 dummy & $-0.599(1.049)$ & \\
\hline \multicolumn{2}{|c|}{$0.287(0.059)^{*}$} \\
\hline Corr $\left(\mathcal{E} x_{i t}, E r_{i t}\right)$ & & \\
\hline
\end{tabular}

* statistically significant at the $\alpha=.05$ level.

Sample size $=1384$, all equations contain 3-digit industry dummy variables 
Table 4: Investment Shares Among Firms with Positive Investment

\begin{tabular}{|l|c|c|}
\hline \multicolumn{1}{|c|}{ Variables } & $\begin{array}{c}\text { Export share of } \\
\text { revenue }\end{array}$ & $\begin{array}{c}\text { R\&D/WT share of } \\
\text { revenue }\end{array}$ \\
\hline intercept & $0.806(0.135)^{*}$ & $0.058(0.040)$ \\
\hline year dummy & $0.015(0.018)$ & $0.021(0.005)^{*}$ \\
\hline entrant dummy & $0.157(0.030)^{*}$ & $-0.027(0.008)^{*}$ \\
\hline $\log ($ age $)$ & $0.011(0.017)$ & $-0.035(0.005)^{*}$ \\
\hline $\log \left(k_{i t}\right)$ & $0.002(0.007)$ & $0.001(0.002)$ \\
\hline $\log \left(p w a g e_{i t}\right)$ & $-0.033(0.022)^{*}$ & $0.011(0.006)$ \\
\hline multiplant dummy & $-0.044(0.023)$ & $0.002(0.007)$ \\
\hline productivity $\left(\omega_{i t}\right)$ & $0.056(0.064)$ & $-0.083(0.020)^{*}$ \\
\hline productivity squared $\left(\omega_{i t}^{2}\right)$ & $-0.062(0.051)$ & $0.037(0.017)^{*}$ \\
\hline export revenue share $t-1$ & $-0.062(0.051)$ & $-0.014(0.009)$ \\
\hline R\&D revenue share $t-1$ & $0.190(0.284)$ & $-0.456(0.056)^{*}$ \\
\hline & & \\
\hline sample size & 987 & 649 \\
\hline $\begin{array}{l}\text { fraction of variance due to firm } \\
\text { effect }\end{array}$ & 0.705 & 0.833 \\
\hline
\end{tabular}

* indicates statistically significant at the $\alpha=.05$ level with a one-tailed test All regressions include 3-digit industry dummies 
Table 5: Survival Equation Estimates

Maximum Likelihood Estimation of Selection Model

Dependent Variable: $S_{\mathrm{t}+1}$

\begin{tabular}{|l|c|}
\hline \multicolumn{1}{|c|}{ Variables } & Coefficient Estimates \\
\hline intercept & $-3.964(1.171)^{*}$ \\
\hline year dummy & $0.108(0.081)$ \\
\hline entrant dummy & $-0.225(0.086)^{*}$ \\
\hline $\log ($ age $)$ & $-0.021(0.060)$ \\
\hline $\log k_{\text {it }}$ & $0.520(0.198)^{*}$ \\
\hline$\left(\log k_{i t}\right)^{2}$ & $-0.018(0.008)^{*}$ \\
\hline $\log \left(p w a g e_{i t}\right)$ & $0.118(0.080)$ \\
\hline multiplant dummy & $-0.025(0.080)$ \\
\hline productivity $\left(\omega_{i t}\right)$ & $0.290(0.158)$ \\
\hline $\begin{array}{l}\text { Choice 1 dummy } \\
\text { Exporting and R\&D/WT }\end{array}$ & $-0.042(0.126)$ \\
\hline $\begin{array}{l}\text { Choice 2 dummy } \\
\text { Exporting but not R\&D/WT }\end{array}$ & $-0.076(0.104)$ \\
\hline $\begin{array}{l}\text { Choice 3 dummy } \\
\text { R\&D/WT but not Exporting }\end{array}$ & $0.084(0.189)$ \\
\hline & \\
\hline Industry dummies & \\
\hline power generation & $0.986(0.218)^{*}$ \\
\hline electrical appliances & $0.418(0.187)^{*}$ \\
\hline wire and cable & $0.576(0.201)^{*}$ \\
\hline lighting & $0.223(0.200)$ \\
\hline repair & $0.836(0.206)^{*}$ \\
\hline video and radio equipment & $0.314(0.174)$ \\
\hline electronic parts and components & $0.657(0.172)^{*}$ \\
\hline $\begin{array}{l}\text { wired communication equipment } \\
\text { batteries }\end{array}$ & $0.468(0.209)^{*}$ \\
\hline non-electronics & $1.123(0.229)^{*}$ \\
\hline batteries & $0.393(0.308)$ \\
\hline
\end{tabular}

* statistically significant at the $\alpha=.05$ level 
Table 6: Productivity Evolution

Maximum Likelihood Estimation of Selection Model

Dependent variable: $\omega_{i t+1}$

\begin{tabular}{|l|c|c|}
\hline \multicolumn{1}{|c|}{ Variable } & \multicolumn{2}{c|}{ Coefficient Estimates } \\
\hline intercept & $0.182(0.063)^{*}$ & $0.179(0.068)^{*}$ \\
\hline year dummy & $0.074(0.016)^{*}$ & $0.072(0.016)^{*}$ \\
\hline productivity $\left(\omega_{i t}\right)$ & $0.279(0.034)^{*}$ & $0.311(0.060)^{*}$ \\
\hline $\begin{array}{l}\text { Choice 1 dummy } \\
\text { Exporting and R\&D/WT }\end{array}$ & $0.078(0.020)^{*}$ & $0.077(0.032)^{*}$ \\
\hline $\begin{array}{l}\text { Choice 2 dummy } \\
\text { Exporting but not R\&D/WT }\end{array}$ & $0.042(0.019)^{*}$ & $0.060(0.030)^{*}$ \\
\hline $\begin{array}{l}\text { Choice 3 dummy } \\
\text { R\&D/WT but not Exporting }\end{array}$ & $0.047(0.034)$ & $0.115(0.055)^{*}$ \\
\hline$\left(\omega_{i t}\right) *$ Choice 1 dummy & & $-0.004(0.080)$ \\
\hline$\left(\omega_{i t}\right) *$ Choice 2 dummy & & $-0.066(0.083)$ \\
\hline$\left(\omega_{i t}\right) *$ Choice 3 dummy & & $-0.263(0.161)$ \\
\hline & & \\
\hline & & $-0.182(0.222)$ \\
\hline $\operatorname{Corr}\left(\xi_{i t}, v_{i t}\right)$ & $-0.152(0.213)$ & -923.288 \\
\hline $\log$ likelihood & -926.998 & 1779 \\
\hline sample size & 1779 & \\
\hline
\end{tabular}

* indicates statistically significant at the $\alpha=.05$ level with a one-tailed test All regressions include 3-digit industry dummies 